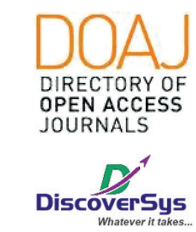

Published by DiscoverSys

\section{Awareness of colorectal cancer risk factor among students at Faculty of Medicine, Udayana University, Bali}

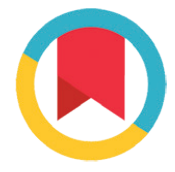

CrossMark

\author{
Huthayan Varmma Rajamanickam, ${ }^{1 *}$ Gede Eka Rusdi Antara ${ }^{2}$
}

\section{ABSTRACT}

Introduction: Colorectal cancer is a major cause of morbidity and mortality throughout the world. To identify the presence of colorectal cancer, screening that is recommended can be carried out. Screening is an important process in every disease including colorectal cancer Method: This is crossectional-descriptive research. 100 samples that met inclusion criteria were included in the research. Samples obtained using consecutive sampling technique. The samples were interviewed to obtain the data used to fill out the questionnaire

Result: $74 \%$ of the student has answered that a history of personal cancer are risk factors of colorectal cancer and al so $88 \%$ of students have answered family history also a risk factor for colorectal cancer. The students have less knowledge on risk factors such as Inflammatory Bowel Disease (64\%) and eating spicy food (60\%). $87 \%$ of students agree that knowledge on colon and rectal cancer is important to prevent colorectal cancer.

Conclusion: Good knowledge of colorectal cancer risk factors among students in medicine faculty, Udayana University.

Keywords: awareness, colorectal cancer, risk factor, student

Cite the Article: Rajamanickam, H.V., Antara, G.E.R. 2019. Awareness of colorectal cancer risk factor among students at Faculty of Medicine, Udayana University, Bali. Intisari Sains Medis 10(2): 249-252. D0I: 10.15562/ism.v10i2.405

ABSTRAK

Latar Belakang: Kanker kolorektal adalah penyebab utama morbiditas dan mortalitas di seluruh dunia. Untuk mengidentifikasi adanya kanker kolorektal, beberapa skrining yang direkomendasikan dapat dilakukan. Skrining adalah proses penting dalam setiap penyakit termasuk kanker kolorektal.

Metode: Ini adalah penelitian deskriptif crossectional. 100 sampel yang memenuhi kriteria inklusi dimasukkan dalam penelitian. Sampel diperoleh dengan menggunakan teknik consecutive sampling. Sampel diwawancarai untuk mendapatkan data yang digunakan untuk mengisi kuesioner.
Hasil: 74\% siswa menjawab dengan benar bahwa riwayat kanker pribadi adalah faktor risiko kanker kolorektal dan juga $88 \%$ siswa menjawab riwayat keluarga juga merupakan faktor risiko kanker kolorektal. Siswa kurang memiliki pengetahuan tentang faktorfaktor risiko seperti Inflammatory Bowel Disease (64\%) dan makan makanan pedas (60\%). 87\% siswa setuju bahwa pengetahuan tentang kanker usus besar dan dubur penting untuk mencegah kanker kolorektal.

Simpulan: Pengetahuan mahasiswa di fakultas kedokteran, Universitas Udayana mengenai faktor risiko kanker kolorektal baik.
${ }^{1}$ Medical Education Program

${ }^{2}$ Surgery Departement/SMF of RSUP Sanglah

Medical Faculty of Udayana University

${ }^{*}$ Correspondence to: Huthayan Varmma Rajamanickam, Medical Education Program, Medical Faculty of Udayana University huthayan@gmail.com

Received: 2019-02-02 Accepted: 2019-03-07 Published: 2019-08-01
Kata kunci: kesadaran, kanker kolorektal, faktor risiko, siswa

Cite Pasal Ini: Rajamanickam, H.V., Antara, G.E.R. 2019. Awareness of colorectal cancer risk factor among students at Faculty of Medicine, Udayana University, Bali. Intisari Sains Medis 10(2): 249-252. D0I: 10.15562/ism.v10i2.405

\section{INTRODUCTION}

Colorectal cancer is a major cause of morbidity and mortality throughout the world. Colorectal cancer causes approximately around $9 \%$ of all cancer incidence. It is the third most cancer worldwide and the fourth most common cancer death. ${ }^{1}$ The mortality rate of colorectal cancer is higher in men compared to women throughout the world and also in South East Asia countries including Indonesia. ${ }^{2}$

Colorectal cancer is cancer that starts either in the colon or the rectum or both in some cases.
This cancer is depending on the origin of cancer. Colorectal cancer starts as a result of the growth of cells on the inner lining of the colon or rectum also known as polyp. ${ }^{3}$ Colorectal cancer also can spread to distant organs and mainly attacks the liver.

Either modifiable factor or non-modifiable factors can cause colorectal. Modifiable factors are more related to an individual's living style and habits. These include smoking, diet, heavy alcohol consumption and also inactive or unhealthy 
lifestyle. The non-modifiable risk factors are more related to family history or disease and also personal disease. The risk of colorectal cancer can be lessened if a person's habit is changed. ${ }^{4}$ Colorectal cancer symptoms are only recognized after the cancer cells or polyps has developed. The common symptoms often recognized are blood in the stool. Other symptoms also may present such as change of bowel habit and also constant abdominal pain. The presence of blood in the stool may also be caused by another disease such as inflammatory bowel disease. ${ }^{5}$

To identify the presence of colorectal cancer, screening that is recommended can be carried out. Screening is an important process in every disease including colorectal cancer. ${ }^{3}$ Regular screening can prevent many cases of colorectal cancer and also find and remove polyps before they turn into cancerous cells. ${ }^{1}$ Screening can be divided into two which are a test to find both colorectal polyps and cancer and another test mainly to identify colorectal cancer. ${ }^{6}$ Flexible sigmoidoscopy, colonoscopy, and computed tomographic colonography are tested that used to identify both polyp and cancerous cells. Meanwhile, tests that find colorectal cancer are a guaiac-based fecal occult blood test (gFOBT), fecal immunochemical test (FIT) and stool DNA test. ${ }^{4,5}$

Once colorectal cancer or polyp presence has been confirmed, it is best to remove the cancerous as fast as possible. Treatment for both colon and rectal will be different because of the anatomical structure. Surgery is the main treatment for both early colon and rectal cancer. Surgery treatment can further divide into colectomy, lymphadenectomy, and metastasectomy. ${ }^{3}$ another treatment choice for colorectal cancer are ablation. Ablation is a treatment that done to destroys small tumors with little harm to nearby tissue. These are mostly used to treat cancer that has spread to the liver and distant organs.

Radiation therapy also can be used. Radiation therapy is a treatment that uses high energy rays. The rays can cause damage to DNA cells. DNA is a chain of chemicals in cells that contain genes. This treatment either will kill the cancer cells or stop the cancer cells from being made. ${ }^{7}$ Chemotherapy or widely known as chemo is the use of drugs to fight cancer is the main choice of treatment in cancer treatment. The drugs may be assessed into a vein or given by mouth. These drugs will travel through them and easily reach the target cells. This treatment is useful for cancer that has spread to distant organs. Chemotherapy also can be used both before and after surgery. Not to forget the side effect, all this treatment has their respective side effects. ${ }^{5}$

Staging of colorectal cancer has been assessed to aid in fighting and making treatment of colorectal easier. Cancer staging is a rating of how far cancer has grown and spread in the body. The staging of colorectal cancer is based on the TNM system. The TNM is based on 3 key pieces of information, which are $\mathrm{T}$ (tumor), $\mathrm{N}$ (nodes) and $\mathrm{M}$ (metastasized). Colorectal cancer can spread over the body, but most common sites are liver and lungs. ${ }^{1}$ Once TNM categories have been determined, this information will be combined in a process called stage grouping and an overall stage of 0, I, II, III, and IV is assigned. ${ }^{3}$

\section{METHODS}

This study was a descriptive cross-sectional study to represent the awareness of colorectal cancer risk factor among students at the Faculty of Medicine, Udayana University. This study was conducted at Udayana University in November 2016 - December 2016. The sample in this study was taken from the students from batch 2013-2016 at Faculty of Medicine, Udayana University which fulfilled the inclusion criteria. The inclusion criteria are the participants were from both genders, stable mental status, and join the research willingly. 100 samples were taken using consecutive sampling technique. The samples were interviewed to obtain the data used to fill out the questionnaire. Descriptive analysis was used to process the data.

\section{RESULT}

One hundred students agreed to participate in this cross-sectional study and to fill their details in the questionnaire. In this cross-sectional study, both male and females participated. Among one hundred students, thirty- four (34\%) students were male students and sixty- six (66\%) students were female. The samples were students age ranging from eighteen to twenty - eight (18-28) years old.

The samples were participated by four academic years which were the year 2013 until the academic year 2016. There were forty -two (42\%) students from the academic year 2013, nineteen (19\%) students from the academic year 2014, fourteen (14\%) students from the academic year 2015 and twenty - five (25\%) students from the academic year 2016. The age range of students from the academic year 2013 was twenty - one till twenty eight (21-28) years old, age range of students from academic year 2014 was twenty -one till twenty six (21-26), nineteen till twenty -two (19-22) years old for academic year 2015 and age ranging from eighteen till twenty - two (18-22) for academic year 2016. Eighty -eight (88\%) of students know what is colorectal cancer meanwhile twelve (12\%) students don't become aware of colorectal cancer. 
Table 1 Knowledge of Colorectal Cancer Risk Factors Among Students

\begin{tabular}{llc}
\hline Items & $\mathbf{N}$ & $\%$ \\
\hline Definition of colorectal cancer & 88 & $88 \%$ \\
Regular smoking habit & 77 & $77 \%$ \\
Consumption of heavy alcohol increase & 85 & $85 \%$ \\
Eating spicy food regularly & 60 & $60 \%$ \\
Obesity & 78 & $78 \%$ \\
Physical inactivity & 77 & $77 \%$ \\
Diabetes & 70 & $70 \%$ \\
Consuming processed meat such as hot dog, nuggets and luncheon meats & 75 & $75 \%$ \\
Consuming meats which were cooked in very high temperatures (frying or grilling) & 79 & $79 \%$ \\
History of personal cancer & 74 & $74 \%$ \\
The family history of cancer & 88 & $88 \%$ \\
History of Inflammatory Bowel Disease (IBD) & 64 & $64 \%$ \\
History of Crohn's Disease & 79 & $79 \%$ \\
\hline
\end{tabular}

Table 2 Understanding the Importance of Colorectal Cancer Screening and Prevention

\begin{tabular}{llc}
\hline Items & N & $\%$ \\
\hline Colon and rectal screening are important in the prevention method & 87 & $87 \%$ \\
Colorectal cancer is best prevented & 90 & $90 \%$ \\
Share information about colorectal cancer with others & 88 & $88 \%$ \\
\hline
\end{tabular}

Participants knowledge about risk factors of colorectal cancer were inquired. The participants were asked to answer yes or no regarding the questions. The percentage of those who answered correctly for each item was presented in Table 1. Participants understanding importance about colorectal cancer screening and prevention were presented in Table 2.

\section{DISCUSSION}

This study is based on undergraduates in medicine faculty of Udayana University in relation with their level of awareness and knowledge about colorectal cancer risk factors and also its prevention. Overall, this study finding revealed a good knowledge and understanding of colorectal cancer. Based on the response, $88 \%$ of students were aware of colorectal cancer.

Another crucial finding related to the same concept, $74 \%$ of the student has answered that history of personal cancer are risk factors of colorectal cancer and also $88 \%$ of students have answered family history also a risk factor for colorectal cancer. More than two-thirds of the students has answered the risk factors for colorectal cancer correctly which were: family history of cancer, (88\%); consumption of heavy alcohol, (85\%); consuming meats which were cooked in high temperature, (79\%); history of Crohn's Disease, (79\%); obesity, (78\%); regular smoking habit, (77\%); physical inactivity, (77\%); consuming processed meat, (75\%); personal history of cancer, (74\%); diabetes, (70\%).

But based on this study, the students have less knowledge on risk factors such as Inflammatory Bowel Disease (64\%) and eating spicy food (60\%). Because these students who participated have less knowledge that colorectal cancer and Inflammatory Bowel Disease shares the same risk factor. Whereas, eating spicy food has less consideration as a major risk factor because residents in Bali, Indonesia consume spices in their daily meal have been a routine throughout their life thus they don't consider this as a factor that affecting their health.

However, on a similar study done at Riyadh, Saudi Arabia, were stated lack of knowledge on colorectal cancer. In this study, only $38 \%$ of the respondent has stated that family history of cancer and $27 \%$ have stated physical inactive as risk factor compared to this study which was $88 \%$. And $77 \%$ respectively. Since all the sample taken among undergraduate's medical students at Udayana University, they seem to have more knowledge. ${ }^{8}$

Other variables that influenced knowledge of colorectal cancer were the academic year which also can be described as the educational level in this study. Among all the students, $12 \%$ has stated 
doesn't know what is colorectal cancer. All these $12 \%$ of students were from the first academic year which was the academic year 2016. These correlated with their understanding of the alimentary system which is taught in the third year of medicine faculty in Udayana University. These findings were in agreement with the majority of previous studies carried on knowledge of cancer in general.

The finding of current work showed that $87 \%$ of students agree that knowledge on colon and rectal cancer is important to prevent colorectal cancer. As a medical student, they must be aware of the symptoms, and the risk factor present's in colorectal cancer. It indirectly gives a safe protection tool against cancer. Furthermore, 90\% of students also agreed that colorectal cancer is best prevented and more than two third of them which were $88 \%$ is willing to share knowledge about colorectal cancer with others.

\section{CONCLUSION}

In conclusion, this study has revealed good knowledge of colorectal cancer risk factors among students in medicine faculty, Udayana University. Educational level seems to play an important role in health awareness in all places. To outspread such understanding and alertness more globally, implementation of awareness program should be established among the public through social media, talks and medical tours.

\section{REFERENCES}

1. S Haggar FA., \& Boushey RP. Colorectal cancer epidemiology: incidence, mortality, survival, and risk factors. Clinics in colon and rectal surgery. 2009. 22(4), 191.

2. WHO. Cancer Country Profiles,2014. Available at www. who.int $>$ country-profiles $>$ idn_en. Accessed $3^{\text {rd }}$ Jan 2015.

3. Ivy Bazensky, Candice Shoobridge-Moran, Linda H. Yoder. Colorectal cancer: An overview of the epidemiology, risk factor, symptoms and screening guidelines. Medsurg Nurs 2007, 16(1):46-51.

4. American Cancer Society. Colorectal Cancer Facts \& Figures 2014-2016. Atlanta, GA: American Cancer Society. 2014.

5. American Cancer Society. Colorectal Cancer Overview. American Cancer Society. 2014. Available at: https://www. cancer.org/cancer/colon-rectal-cancer/about/what-is-colorectal-cancer.html. Accessed $5^{\text {th }}$ Jan 2015.

6. American Cancer Society. Cancer Prevention \& Early Detection Facts \& Figures 2015-2016. Atlanta: American Cancer Society. 2015.

7. NCCN Guidelines for Patients. Colon Cancer. National Comprehensive Cancer Network, Version 1,2014.

8. Al Wutayd O., Alamri F., Ali AM., Kassim KA., \& Ibrahim AK. Colorectal cancer risk factors: a study of knowledge, attitude, and practice among adults in Riyadh, Saudi Arabia. Cancer Research Journal. 2015. 3(5), 94-99.

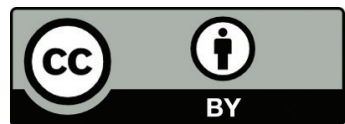

This work is licensed under a Creative Commons Attribution 